\title{
HR-Mediated Defense Response is Overcome at High Temperatures in Capsicum Species
}

\author{
Bong Nam Chung ${ }^{*}$, Joung-Ho Lee ${ }^{2}$, Byoung-Cheorl Kang ${ }^{2}$, Sang Wook Koh ${ }^{3}$, Jae Ho Joa ${ }^{3}$, Kyung San Choi ${ }^{3}$, \\ and Jeong Joon Ahn ${ }^{3}$ \\ ${ }^{I}$ National Institute of Horticultural \& Herbal Science, RDA, Wanju 55365, Korea \\ ${ }^{2}$ Department of Plant Science College of Agriculture and Life Sciences, Seoul National University, Seoul 08826, Korea \\ ${ }^{3}$ Research Institute of Climate Change and Agriculture, Jeju 63240, Korea
}

(Received on June 10, 2017; Revised on September 26, 2017; Accepted on September 27, 2017)

Resistance to Tomato spotted wilt virus isolated from paprika (TSWV-Pap) was overcome at high temperatures $\left(30 \pm 2{ }^{\circ} \mathrm{C}\right)$ in both accessions of Capsicum annuum S3669 (Hana Seed Company) and C. chinense PI15225 (AVRDC Vegetable Genetic Resources). S3669 and PI15225, which carrying the $T s w$ gene, were mechanically inoculated with TSWV-Pap, and then maintained in growth chambers at temperatures ranging from 15 $\pm 2^{\circ} \mathrm{C}$ to $30 \pm 2^{\circ} \mathrm{C}$ (in $5^{\circ} \mathrm{C}$ increments). Seven days post inoculation (dpi), a hypersensitivity reaction (HR) was induced in inoculated leaves of PI152225 and S3669 plants maintained at $25^{\circ} \mathrm{C} \pm 2^{\circ} \mathrm{C}$. Meanwhile, necrotic spots were formed in upper leaves of $33 \%$ of PI15225 plants maintained at $30 \pm 2{ }^{\circ} \mathrm{C}$, while systemic mottle symptoms developed in $50 \%$ of $\mathrm{S3669}$ plants inoculated. By 15 dpi, $25 \%$ of $\mathbf{S 3 6 6 9}$ plants had recovered from systemic mottling induced at $30 \pm 2^{\circ} \mathrm{C}$. These results demonstrated that resistance to TSWV-Pap can be overcome at higher temperatures in both $C$. chinense and $C$. annuum. This is the first study reporting the determination of temperatures at which TSWV resistance is overcome in a $C$. annuum genetic resource expressing the $T s w$ gene. Our results indicated that TSWV resistance shown from pepper plants possess the $T s w$ gene could be overcome at high temperature. Thus, breeders

\footnotetext{
*Corresponding author.

Phone) +82-63-238-6340, FAX) +82-63-238-6305

E-mail) chbn7567@korea.kr

(c) This is an Open Access article distributed under the terms of the Creative Commons Attribution Non-Commercial License (http:// creativecommons.org/licenses/by-nc/4.0) which permits unrestricted noncommercial use, distribution, and reproduction in any medium, provided the original work is properly cited.
}

Articles can be freely viewed online at www.ppjonline.org. should conduct evaluation of TSWV resistance in pepper cultivars at higher temperature than $30^{\circ} \mathrm{C}$ (constant temperature).

Keywords : HR, recovery, resistance, temperature, $T s w$ gene

Handling Associate Editor : Sohn, Kee Hoon

Tomato spotted wilt virus (TSWV) was first observed in Australia in 1915 (Brittlebank, 1919), and was identified as a viral disease in 1930 (Samuel et al., 1930). TSWV has a wide host range of more than 800 species in 82 families and is spread throughout the world. In Korea, TSWV was first observed on paprika in Yesan, Chungcheongnamdo Province in 2004 (Kim et al., 2004); at present, it is widespread in open fields of cultivated Capsicum annuиm. TSWV is transmitted by thrips. Nine species of thrips are reported as TSWV vectors (Gibbs, 1983). As pesticides become less available, or less effective due to insecticide resistance in the thrips (Gao et al., 2012), alternative strategies are needed for crop protection. One such strategy is to use resistant cultivars.

Resistance of pepper plants to TSWV is conferred in both PI152225 and PI159236 lines by a single dominant gene $(T s w)$, which is resistant to a broad range of TSWV isolates (Black et al., 1996). The Tsw gene controls systemic spread of TSWV via a hypersensitivity reaction (HR) in the host plants (Black et al., 1991; Boiteux, 1995; Moury et al., 1997). The HR mechanism is known to be strongly influenced by ambient temperature, as well as physiological conditions of plants (Moury et al., 1998; Roselló et al., 1997; Soler et al., 1998).

Climate change models predict a progressive increase of 


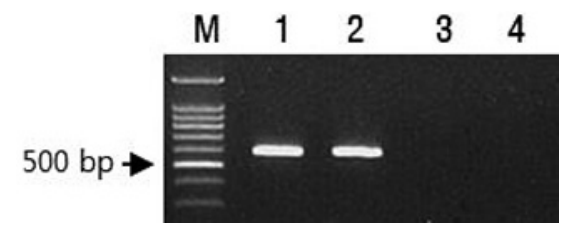

Fig. 1. Ampication of Tsw gene from 'PI152225', 'S3669', 'Hanabero' and 'Yeokgangsumunjang' uing a Tsw gene specific primer pair Tsw 600F/R. Approximately 600 bp amplicons are shown from both PI152225 and S3669. However, $600 \mathrm{bp}$ amplicon are not shown from both 'Hanabero' and 'Yeokgangsumunjang'. M: 100bp DNA ladder, 1: 'PI152225', 2: 'S3669', 3: 'Hanabero', 4: 'Yeokgangsumunjang'.

the global average temperature of up to $4.6^{\circ} \mathrm{C}$ by the year 2100 (IPCC, 2014), with higher latitudes warming faster than lower latitudes (Jones, 2009). The dynamics of plant virus epidemics and the losses they cause are likely to be influenced greatly by the direct consequences of climate change, such as increased temperature, and indirectly by the abundance and activity of pathogen vectors (Jones, 2009). In this study, we investigated the effect of temperature on TSWV-Pap infection in both $C$. chinense and $C$. annuum, demonstrating the resistance conferred by the $T s w$ gene via HR. We found that $T s w$-mediated resistance is overcome in both $C$. chinense and $C$ annuum species at high temperatures $\left(30 \pm 2{ }^{\circ} \mathrm{C}\right)$.

Accessions of $C$. chinense accession PI152225 and $C$. annuum S3669, carrying the $T s w$ gene, were obtained from AVRDC Vegetable Genetic Resources (Taiwan) and the Hana Seed Company (Korea), respectively. 'Habanero' and 'Yeokgangsumumjang' cultivars were used as TSWVsusceptible controls for $C$. chinense and $C$. annuum, respectively. The presence of $T s w$ gene from both PI152225 and S3669 was confirmed by polymerase chain reaction using a pairs of primer (Tsw 600F/ Tsw 600R) (Fig. 1). However, there were no $T s w$ gene specific 600bp ampli- cons from both 'Hanabero' and 'Yeokgangsumumjang' (Fig. 1). The sequence of forward primer (Tsw 600F) was homologous to nucleotides 1501-24 of GenBank accession no. KT751527 and those of reverse primer (Tsw 600R) was complementary to nucleotides 2077-100 of the Tsw accession.

The TSWV inoculum source used in this study was TSWV-Pap isolated from paprika (Chung et al., 2012). Two true leaf stages of pepper seedlings were inoculated with TSWV-Pap-infected Nicotiana rustica crude sap in $0.05 \mathrm{M}$ sodium phosphate buffer, $\mathrm{pH} 7.0$, and were maintained at constant temperatures ranging from $15 \pm 2{ }^{\circ} \mathrm{C}$ to $30 \pm 2^{\circ} \mathrm{C}$ (in $5^{\circ} \mathrm{C}$ increments) in growth chambers $(16 \mathrm{~h}$ day $/ 8 \mathrm{~h}$ night, $65 \%$ relative humidity) until 20 days postinoculation (dpi). Ten and 58 plants were tested for S3669 and PI152225, respectively. Fifty eight plants for PI152225 and 15 plants for Hanabero represent the total number from three experiments. We used mechanical transmission instead of thrips vector to inoculate each test plant with the same virus titer.

TSWV-Pap infection was confirmed by reverse transcription polymerase chain reaction (RT-PCR). Total RNA was isolated from leaf tissue using RNeasy Plant Mini Kit (Qiagen, Netherlands) according to the manufacturer's instructions. The RT-PCR method and primers were the same as those used in a previous study (Chung et al., 2006). To avoid generation of defective strains that might occur in successive mechanical inoculations (Resende et al., 1991), virus inoculum plants were prepared from the TSWV-Pap isolate source for each experiment.

For Northern blot analysis, total RNA samples were isolated from either mock-inoculated or virus-infected plants using a RNeasy Plant Mini Kit (Qiagen), and were fractionated by electrophoresis in agarose gels under denaturing conditions ( $6 \%$ formaldehyde), blotted to nitrocellulose membranes, and hybridized with the specified digoxigenin-

Table 1. Effect of temperature on infection by of Tomato spotted wilt virus-Pap in Capsicum species at 10 days post inoculation

\begin{tabular}{|c|c|c|c|c|c|c|c|c|c|c|c|c|c|c|c|}
\hline \multirow{3}{*}{$\begin{array}{l}\text { Capsicum } \\
\text { Species }\end{array}$} & \multirow{3}{*}{ (cultivar) } & \multirow{3}{*}{$\begin{array}{l}\text { No. of } \\
\text { plants } \\
\text { tested }\end{array}$} & \multicolumn{13}{|c|}{$\%$ of plants infected with TSWV-Pap } \\
\hline & & & \multicolumn{3}{|c|}{$15 \pm 2^{\circ} \mathrm{C}$} & \multicolumn{3}{|c|}{$20 \pm 2^{\circ} \mathrm{C}$} & \multicolumn{3}{|c|}{$25 \pm 2^{\circ} \mathrm{C}$} & \multicolumn{4}{|c|}{$30 \pm 2^{\circ} \mathrm{C}$} \\
\hline & & & NI & HR & SI & NI & HR & SI & NI & HR & SI & NI & HR & SI & $\mathrm{SI}+\mathrm{HR}$ \\
\hline \multirow{2}{*}{ C. chinense } & Hanabero $(\mathrm{S})$ & 15 & 0 & 0 & 100 & 0 & 0 & 100 & 0 & 0 & 100 & 0 & 0 & 100 & 0 \\
\hline & PI152225 (R) & 58 & 95 & 5 & 0 & 95 & 5 & 0 & 27 & 73 & 0 & 50 & 17 & 33 & 17 \\
\hline \multirow{2}{*}{ C. аппиит } & $\begin{array}{l}\text { Yeokgang } \\
\text { sumun jang }(\mathrm{S})\end{array}$ & 27 & 96 & 0 & 4 & 11 & 0 & 89 & 11 & 0 & 89 & 22 & 0 & 78 & 0 \\
\hline & S3669 (R) & 10 & 20 & 80 & 0 & 60 & 40 & 0 & 80 & 20 & 0 & 30 & 20 & $\begin{array}{c}50 \\
(25)^{\mathrm{z}}\end{array}$ & 0 \\
\hline
\end{tabular}

NI, non-infection; HR, hypersensitive reaction; SI, systemic infection.

${ }^{z_{0}} \%$ of plants recovered from infection. 
labeled RNA probes for TSWV segment M. Nonradioactive blots were washed, incubated with antidigoxigenin antibody (Roche Diagnostics, UK), and exposed following the manufacturer's instructions as described in a prior study (Canto and Palukaitis, 2001). The TSWV probe was specific to the sequences encoding the NSm protein in TSWV segment M. Enzyme-linked immunosorbent assay (ELISA) was conducted using Agdia (Indiana, USA) product SRA39300 according to the manufacturer's instructions.

About $73 \%$ of PI152225 plants maintained at $25 \pm 2{ }^{\circ} \mathrm{C}$ produced HR on inoculated leaves, while $33 \%$ of plants maintained at $30 \pm 2{ }^{\circ} \mathrm{C}$ formed necrotic local lesions in an

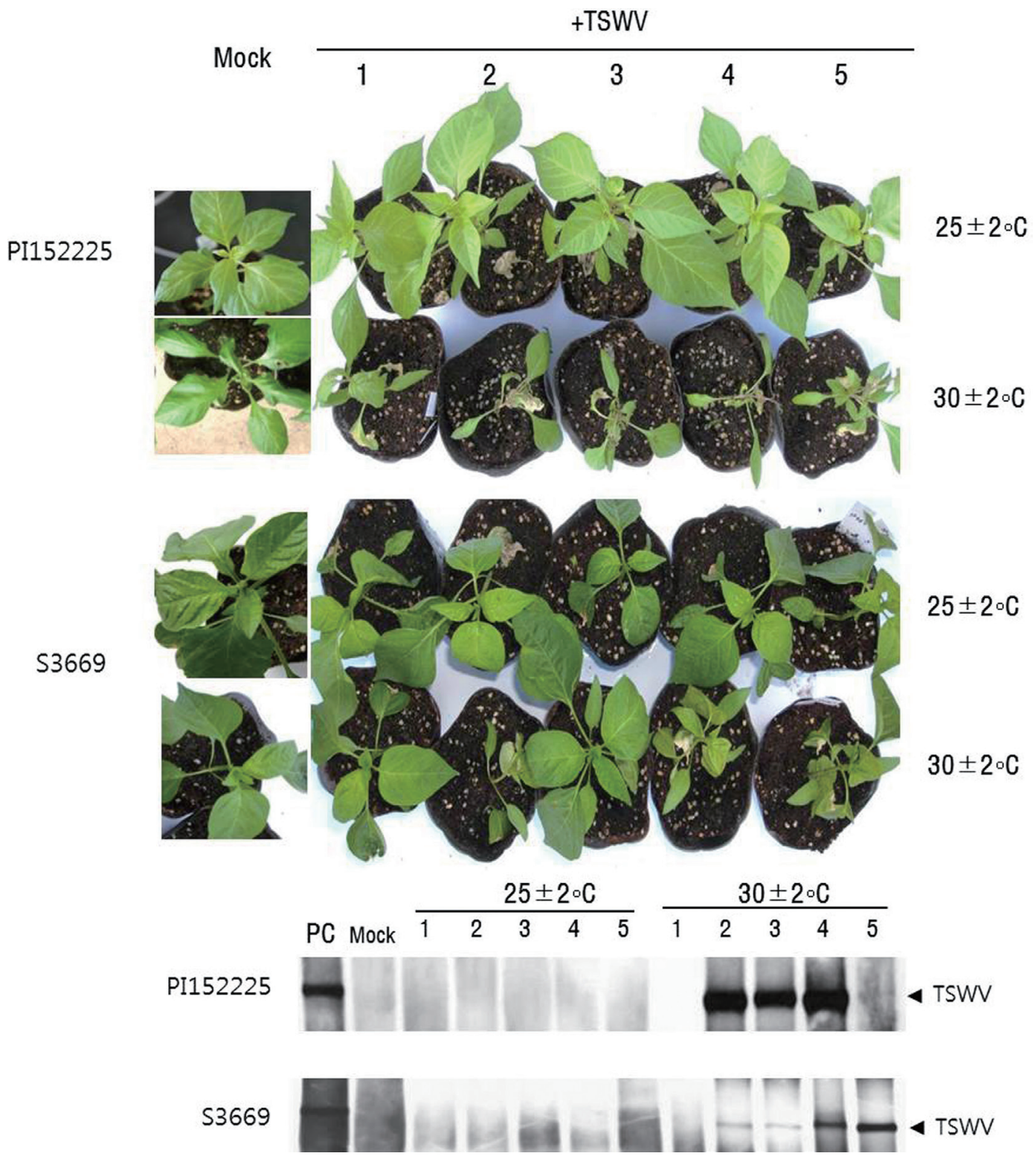

Fig. 2. (A) Symptom expression in C. chinense PI152225 and C. annuum S3669 mechanically inoculated with Tomato spotted wilt virus (TSWV)-Pap: PI152225 plants maintained at $25 \pm 2^{\circ} \mathrm{C}$ developed necrotic spots on inoculated leaves, while plants maintained at $30 \pm 2^{\circ} \mathrm{C}$ formed necrotic spots moving upward from leaf to leaf (non-self-limiting HR). HR reaction was observed in leaves of inoculated S3669 plants maintained at $25 \pm 2^{\circ} \mathrm{C}$, while systemic infection was observed in plants at $30 \pm 2^{\circ} \mathrm{C}$. (B) Detection of TSWV RNA by northern blot hybridization. Total RNA was extracted from the upper leaves of $C$. chinense PI152225 and C. annuum S3669 maintained at $25 \pm$ $2^{\circ} \mathrm{C}$ and $30 \pm 2^{\circ} \mathrm{C}$ at 10 dpi with TSWV-Pap. Five plants of each species were used for total RNA extraction. RNA was fractionated by agarose gel electrophoresis, blotted to nitrocellulose membranes, and hybridized with the specified digoxigenin-labeled RNA probes for TSWV NSm (PC = positive control; NC = negative control). PI152225 2nd, 3rd, and 4th plants, and S3669 from 2nd to 5th plants, maintained at $30 \pm 2^{\circ} \mathrm{C}$, revealed TSWV-specific bands, while plants maintained at $25 \pm 2{ }^{\circ} \mathrm{C}$ did not exhibit TSWV-specific bands. 


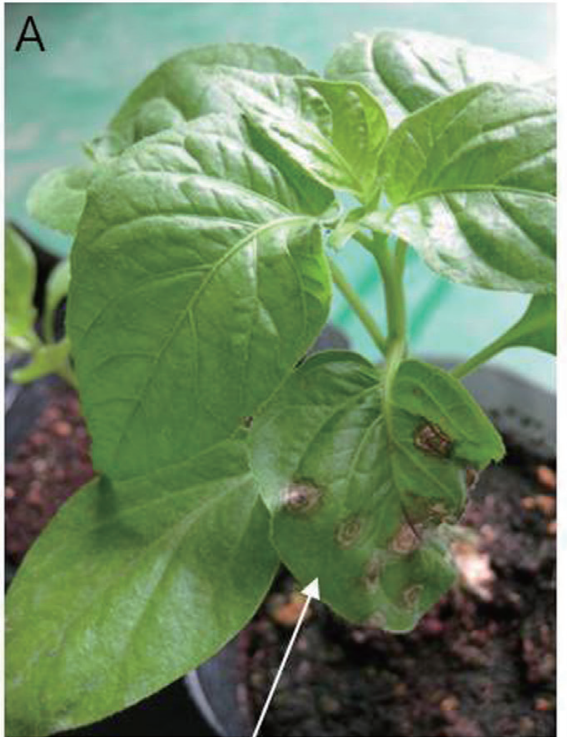

Inoculated leaf

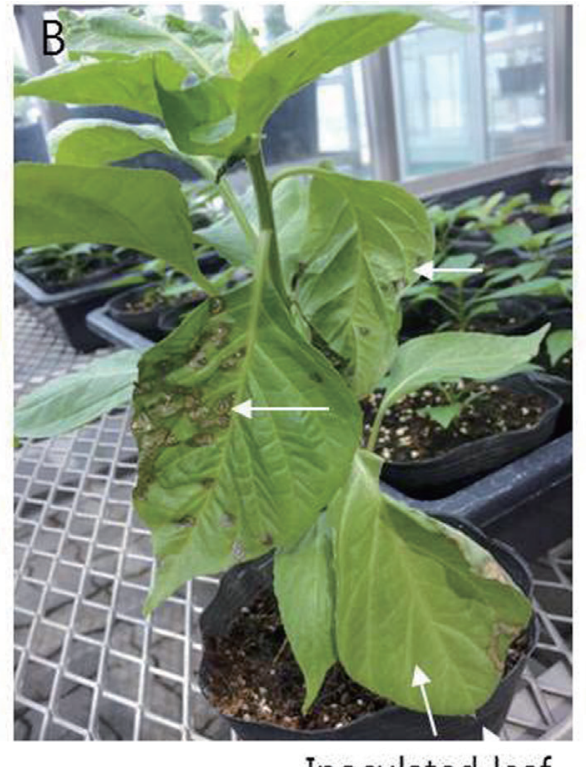

Inoculated leaf
Fig. 3. Response of PI152225 to infection by Tomato spotted wilt virus (TSWV). (A) HR is shown from plants maintained at $25 \pm 2^{\circ} \mathrm{C}$. (B) Systemic necrosis, indicated by arrows in upper leaves, shown in plants maintained at $30 \pm 2^{\circ} \mathrm{C}$. Virus infection was determined by RT-PCR at 10 dpi. upward direction from leaf to leaf (non-self-limiting HR), revealing movement of virus to upper leaves (Table 1, Fig. 2). All $17 \%$ of PI152225 plants formed HR on inoculated leaves at $30 \pm 2^{\circ} \mathrm{C}$ revealed systemic necrosis. HR reaction was observed in inoculated leaves of $20 \%$ of S3669 plants tested at $25 \pm 2^{\circ} \mathrm{C}$, while systemic infection was ob- served in $50 \%$ of the plants maintained at $30 \pm 2^{\circ} \mathrm{C}$ (Table 1, Fig. 2). Mock plants of both PI152225 and S3669 did not show viral symptom (Fig. 2). Non of the S3669 plants formed $\mathrm{HR}$ on inoculated leaves at $30 \pm 2{ }^{\circ} \mathrm{C}$ revealed systemic infection (Table 1). Meanwhile, TSWV-susceptible cultivars 'Habanero' and 'Yeokgang-sumumjang' revealed
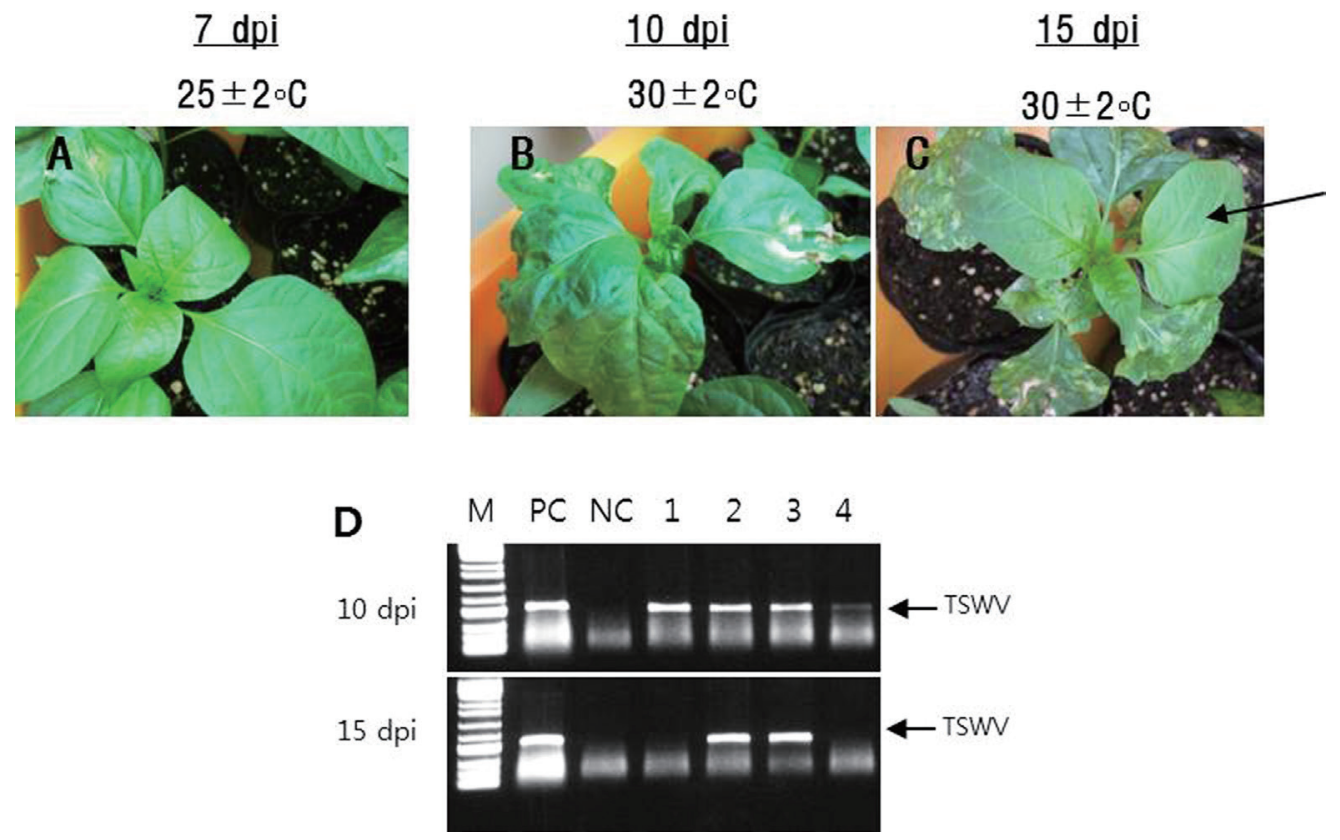

Fig. 4. Symptom expression of Capsicum annuum S3669 mechanically inoculated with Tomato spotted wilt virus (TSWV)-Pap and subsequently maintained at $25 \pm 2^{\circ} \mathrm{C}$ and $30 \pm 2^{\circ} \mathrm{C}$. A). A) Hypersensitivity reaction (HR) occurred in inoculated leaves of plants maintained at $25 \pm 2^{\circ} \mathrm{C}$ at $7 \mathrm{dpi}$ without systemic infection; B) systemic infection of plants maintained at $30 \pm 2^{\circ} \mathrm{C}$ at $10 \mathrm{dpi}$; $\mathrm{C}$ ) recovery from infection at 15 dpi (arrow); D) RT-PCR with RNA extracted from 4 plants that exhibited systemic symptoms revealed TSWV-specific bands at 10 dpi, while TSWV-specific bands were not observed in 2 of 4 plants at 15 dpi. 
systemic infection with $100 \%$ and $4-89 \%$ depend on temperature, respectively (Table 1).

Systemic infection of both S3669 and PI152225 plants was confirmed by detection of TSWV RNA using northern blot analysis (Fig. 2), and by detection of coat proteins using ELISA (data not shown). TSWV-specific bands were detected in the upper leaves of PI152225 2nd, 3rd, and 4th plants and S3669 2nd to 5th plants, while plants maintained at $25 \pm 2{ }^{\circ} \mathrm{C}$ did not exhibit TSWV-specific bands (Fig. 5). Mock plants of both PI152225 and S3669 did not show TSWV-specific bands (Fig. 2).

PI152225 plants formed necrotic spots in upper leaves at $30 \pm 2^{\circ} \mathrm{C}$ revealed progress of necrotic symptoms from A to $\mathrm{C}$ as time passed (Fig. 3). Over time, plants with systemic necrosis withered due to stem necrosis (Fig. 3). HR reaction was observed in inoculated leaves of S3669 plants at $25 \pm 2^{\circ} \mathrm{C}$ at $7 \mathrm{dpi}$, while systemic mottle infection was observed in plants maintained at $30 \pm 2^{\circ} \mathrm{C}$ (Fig. 4). At 15 dpi, viral symptoms did not appear in leaves that had newly emerged, and the virus was not detected in symptomless upper leaves by RT-PCR (Fig. 4C). At 10 dpi, RT-PCR of 4 plants exhibiting systemic symptoms displayed TSWVspecific bands, while at $15 \mathrm{dpi}$, TSWV-specific bands were not observed in 2 of 4 plants (Fig. 4D).

Both TSWV-susceptible 'Habanero' and 'Yeokgangsumumjang' cultivars exhibited systemic mottle symptoms at 15-20 dpi (Fig. 5). 'Habanero' exhibited different symptoms depending on the temperatures maintained after inoculation with the virus. More severe symptoms were ob- served in plants maintained at $25 \pm 2^{\circ} \mathrm{C}$ and $30 \pm 2^{\circ} \mathrm{C}$ than those maintained at $15 \pm 2{ }^{\circ} \mathrm{C}$ and $20 \pm 2^{\circ} \mathrm{C}$. 'Yeokgangsumumjang' exhibited the most severe mottle symptoms, with necrosis of plants maintained at $25 \pm 2^{\circ} \mathrm{C}$ (Fig. 5).

$T s w$ gene-based resistance was overcome in both $C$. chinense (PI152225) and C. annuum (S3669) genetic resources at $30 \pm 2^{\circ} \mathrm{C}$. PI152225 exhibited HR in inoculated leaves, followed by systemic necrotic local lesions, while S3669 displayed systemic mottle symptoms. Generally, necrotic local lesions induced by HR are self-limiting in size (Pennazio, 1995; Solymosy, 1970); however, in this study, local lesions were formed systemically in the upper leaves at high temperatures, showing that the virus was no longer confined to local lesions but able to spread to upper leaves. Our study demonstrated that the manifestation of systemic infection symptoms differs depending on the genetic resources of $T s w$-carrying Capsicum species being used. PI152225 exhibited non-self-limiting necrotic spots in the upper leaves, while S3669 displayed systemic mottle symptoms.

The PI152225 and PI159236 C. chinense accessions are known to exhibit TSWV resistance; they develop HR without systemic infection (Dufour et al., 1989; Makkouk and Kumari, 1993). In this study, maintaining PI152225 plants at high temperatures $\left(30 \pm 2^{\circ} \mathrm{C}\right)$ after mechanical TSWV-Pap inoculation led to a modification of the virus symptom pattern in plant tissues, resulting in HR in inoculated leaves, followed by necrotic local lesions in the upper leaves. Similar breaking of TSWV resistance due to
Hanabero(S)-20dpi

Yeokgangsumumjang(S)-15dpi

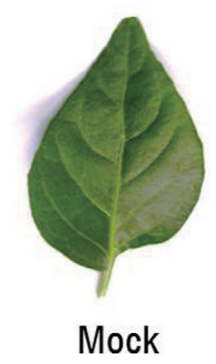

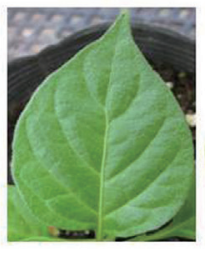
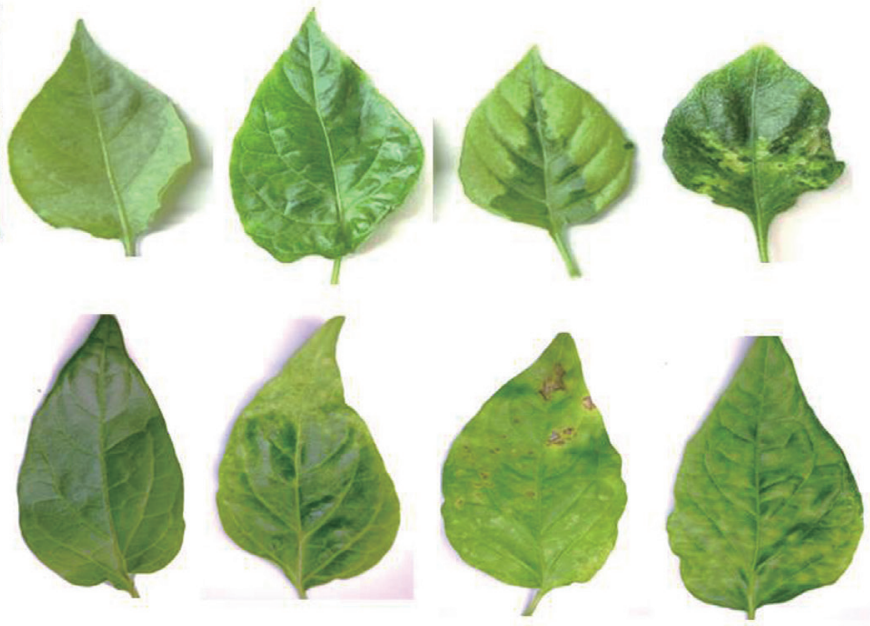

$15 \pm 2 \circ \mathrm{C}$

$20 \pm 2 \circ \mathrm{C}$

$25 \pm 2 \circ \mathrm{C}$

$30 \pm 2 \circ \mathrm{C}$

Fig. 5. Symptoms as influenced by temperatures maintained after mechanical inoculation of Capsicum species with Tomato spotted wilt virus-Pap. Upper panel, C. chinense 'Habanero' exhibiting more severe symptoms at 20 dpi at both $25 \pm 2{ }^{\circ} \mathrm{C}$ and $30 \pm 2^{\circ} \mathrm{C}$ than at $15 \pm 2{ }^{\circ} \mathrm{C}$ and $20 \pm 2{ }^{\circ} \mathrm{C}$; lower panel, C. annuum 'Yeokgangsumumjang' exhibiting the most severe symptom at 15 dpi, yellowing with necrosis, at $25 \pm 2{ }^{\circ} \mathrm{C}$. 
high temperatures has been previously reported. Roggero et al. (1996) found a break in TSWV resistance when $C$. chinense plants were maintained at a constant $33^{\circ} \mathrm{C}$. Virus movement in PI159236 was faster when C. chinense plants were kept at a $30 / 18^{\circ} \mathrm{C}$ day/night temperature regime (Soler et al., 1988). The same phenomenon has been observed with the PI152225 accession, so increased viral accumulation may allow the virus to reach the phloem when the leaf acts as a photosynthate exporter (Soler et al., 1988). Breaking of Tobacco mosaic virus (TMV) resistance at high temperatures has also been reported (Weststeijn, 1984). During $\mathrm{HR}$ in tobacco expressing the $\mathrm{N}$ gene, tissue necrosis and resistance to TMV were overcome at temperatures above $28^{\circ} \mathrm{C}$, followed by systemic infection without HR. Zhu et al. (2010) showed that mutation of the $\mathrm{N}$ gene and another gene SNC1 could provide HR at higher temperatures. In the current study, $C$. annuum S3669 inoculated with TSWV-Pap similarly displayed systemic mottle symptom without $\mathrm{HR}$ at high temperatures.

Although HR occurred on inoculated PI152225 leaves, viruses were not confined to the necrotic legions but moved systematically to the upper leaves. This finding supports the hypothesis that necrosis and virus localization are controlled by two different mechanisms (Pennazio, 1995). Pennazio (1995) proposed that high temperatures result in the blocking of virus localization, which is known to confer extreme resistance to the whole plant, leading to interference with virus replication by antiviral factors synthesized during HR, and inhibition of the cell-to-cell spread of virus infection. Samuel (1930) also found that higher temperatures inhibit HR. Taliansky et al. (1994) suggested that the ability of the virus to overcome HR could be related to high virus replication capacity in the host cells.

We assume that the differences that we observed in upper leaf symptoms between S3669 and PI152225 at high temperatures were due to differences in heat tolerance. A recent study (Chung et al., 2016) found that Potato virus $\mathrm{Y}-\mathrm{O}$ and Potato virus A tended to accumulate at higher temperatures $\left(30 \pm 2^{\circ} \mathrm{C}\right)$ in early stages of infection, but that as time passed, virus accumulation was reduced, indicating an increase of host plant resistance over time. The modification of virus distribution has also been observed in wheat plants resistant to Wheat mosaic virus as temperature increases (Myers et al., 1993), as high temperatures affect the tridimensional structure of coat proteins, which act as elicitors of HR in TMV.

In this study, $25 \%$ of the $\mathrm{S} 3669$ plants that displayed systemic infection symptoms at $30 \pm 2{ }^{\circ} \mathrm{C}$ recovered from infection as time passed. Newly emerged leaves were symptomless and virus-free. This suggests that different resistance genes will behave differently at higher temperature. Symptom recovery in virus-infected plants is characterized by the emergence of asymptomatic leaves after systemic symptomatic infection, and has been linked to induction of RNA silencing (Baulcombe, 2004; Macdiarmid, 2005). Szittya et al. (2003) suggested that RNA silencingmediated plant defenses are temperature-dependent and that levels of siRNA increase gradually with rising temperatures. One recent study (Ghoshal and Sanfacon, 2014) found that plant growth at lower temperatures $\left(21^{\circ} \mathrm{C}\right.$ rather than $27^{\circ} \mathrm{C}$ ) alleviated the recovery of ToRSV-infected plants. This recovery was associated with AGO1 siRNA, which plays a central role in RNA silencing.

The purpose of this study was to investigate if the virus could overcome TSWV resistance conferred by the $T s w$ gene in Capsicum species including $C$. anпuиm at elevated temperature in the future. Thus, to determine the critical temperature at which virus resistance conferred by the $T s w$ gene be overcome, this study was conducted at constant temperature not at diurnal-nocturnal variation temperature. Conclusively we found that TSWV resistance shown from pepper plants possess the $T s w$ gene could reveal systemic infection at $30 \pm 2{ }^{\circ} \mathrm{C}$. Our results indicated that TSWV resistance shown from pepper plants possess the $T s w$ gene could be overcome at high temperature in the future according to climate change scenarios (IPCC, 2014). Thus, breeders should conduct evaluation of TSWV resistance in pepper cultivars at high temperature $\left(30^{\circ} \mathrm{C}\right)$ than at ambient.

\section{Acknowledgments}

This work was carried out with the support of the Research Program for Agriculture Science \& Technology Development (Project No. PJ010246), Rural Development Administration, Republic of Korea.

\section{References}

Baulcombe, D. 2004. RNA silencing in plants. Nature 431:356363.

Black, L. L., Hobbs, H. A. and Gatti, J. M. 1991. Tomato spotted wilt virus resistance in Capsicum chinense PI152225 and 159236. Plant Dis. 75:863.

Black, L. L., Hobbs, H. A. and Kammerlohr, D. S. 1996. Resistance of Capsicum chinense lines to tomato spotted wilt virus from Louisiana, USA, and inheritance of resistance. Acta Hortic. 431:393-401.

Boiteux, L. S. 1995. Allelic relationships between genes for resistance to tomato spotted wilt tospovirus in Capsicum chinense. Theor. Appl. Genet. 90:146-149. 
Brittlebank, C. C. 1919. Tomato diseases. J. Agr., Victoria, Australia 17:213-235.

Canto, T. and Palukaitis, P. 2001. A cucumber mosaic virus (CMV) RNA 1 transgene mediates suppression of the homologous viral RNA 1 constitutively and prevents CMV entry into the phloem. J. Virol. 75:9114-9120.

Chung, B. N., Choi, H. S., Yang, E. Y. Cho, J. D., Cho, I. S., Choi, G. S. and Choi, S. K. 2012. Tomato spotted wilt virus isolates giving different infection in Commercial Capsicum annuum cultivars. Plant Pathol. J. 28:87-92.

Chung, B. N., Pak, H. S., Jung, J. A. and Kim, J. S. 2006. Occurrence of Tomato spotted wilt virus in Chrysanthemum (Dendranthema grandiflorum) in Korea. Plant Pathol. J. 22:230234.

Chung, B. N., Tomas, C., Franscico, T., Choi, K. S., Joa, J. H., Ahn, J. J., Kim, C. H. and Do, K. S. 2016. The effects of high temperature on infection by Potato virus $Y$, Potato virus A, and Potato leafroll virus. Plant Pathol. J. 32:321-328.

Dufour, O., Palloix, A., Gebre Selassie, K., Pochard, E. and Marchoux, G. 1989. The distribution of cucumber mosaic virus in resistant and susceptible plants of pepper. Can. J. Bot. 67:655-660.

Gao, Y., Lei, Z. and Reitz, S. R. 2012. Western flower thrips resistance to insecticides: detection, mechanisms and management strategies. Pest Manag. Sci. 68:1111-1121.

Ghoshal, B. and Sanfaçon, H. 2014. Temperature-dependent symptom recovery in Nicotiana benthamiana plants infected with tomato ringspot virus is associated with reduced translation of viral RNA2 and requires ARGONAUTE1. Virology 456-457:188-197.

Gibbs, A. J. 1983. Tomato spotted wilt tospovirus. Plant viruses online: descriptions and lists from the VIDE Database.

IPCC. 2014. Climate change 2014: the physical science basis. Contribution of working group I to the fourth assessment report of the intergovernmental panel on climate change. Cambridge University Press, Cambridge, United Kingdom / NY, USA. 996 pp.

Jones, R. A. 2009. Plant virus emergence and evolution: origins, new encounter scenarios, factors driving emergence, effects of changing world conditions, and prospects for control. Virus Res. 141:113-130.

Kim, J. H., Choi, G. S., Kim, J. S. and Choi, C. K. 2004. Characterization of Tomato spotted wilt virus from paprika in Korea. Plant Pathol. J. 20:297-301.

Macdiarmid, R. 2005. RNA silencing in productive virus infection. Annu. Rev. Phytopathol. 43:523-544.

Makkouk, K. M. and Kumari, S. G. 1993. Movement of bean yellow mosaic virus in susceptible and resistant faba bean genotypes. Fabis Newsletter 32:35-37.

Moury, B., Palloix, A., Selassie-Gebre, K. and Marchoux, G. 1997. Hypersensitive resistance to tomato spotted wilt virus in three Capsicum chinense accessions is controlled by a single gene and is overcome by virulent strains. Euphytica 94:45-52.

Moury, B., Selassie-Gebre, K., Marchoux, G., Daubeze, A. M. and Palloix, A. 1998. High temperature effects on hypersensitive resistance to tomato spotted wilt tospovirus (TSWV) in pepper (Capsicum chinense Jacq.). Euro. J. Plant Pathol. 104:489-498.

Myers, L. D., Sherwood, J. L., Siegerist, W. C. and Hunger, R. M. 1993. Temperature-influenced virus movement in expression of resistance to soilborne wheat mosaic virus in hard red winter wheat (Triticum aestivum). Phytopathology 83:548-551.

Pennazio, S. 1995. The hypersensitive reaction of higher plants to viruses: A molecular approach. Microbiologica 18:229-240.

Resende, R. de O., de Haan, P., de Avila, A. C., Kitajima, E. W., Kormelink, R., Goldbach, R. and Peters, D. 1991. Generation of envelope and defective interfering RNA mutants of tomato spotted wilt virus by mechanical passage. J. Gen. Virol. 72:2375-2383.

Roggero, P., Lisa, V., Nervo, G. and Pennazio, S. 1996. Continuous high temperature can break the hypersensitivity of Capsicum chinense 'PI152225' to tomato spotted wilt tospovirus (TSWV). Phytopathologia Mediterranea 35:117-120.

Rosellò, S., Diez, M. J. and Nuez, F. 1997. Utilization of Capsicum sp. resistance to TSWV in pepper breeding. Capsicum and Eggplant Newsletters 16:87-90.

Samuel, G., Bald, J. G. and Pittman, H. A. 1930. Investigation on 'spotted wilt' of tomatoes. Aust. Council Sci. Ind. Res. Bull. 44:64.

Soler, S., Diez, M. J. and Nuez, F. 1998. Effect of temperature regime and growth stage interaction on pattern of virus presence in TSWV-resistant accessions of Capsicum chinense. Plant Dis. 82:1199-1204.

Solymosy, F. 1970. Biochemical aspects of hypersensitivity to virus infection in plants. Acta Phytopathol. Acad. Sci. Hung. 5:55-63.

Szittya, G., Silhavy, D., Molnár, A., Havelda, Z., Lovas, A., Lakatos, L., Bánfalvi, Z. and Burgyán, J. 2003. Low temperature inhibits RNA silencing-mediated defense by the control of siRNA generation. EMBO J. 22:633-640.

Taliansky, M., Aranda, M. A. and Garciaarenal, F. 1994. Differential invasion by tobamoviruses of Nictiana megalosiphon following the hypersensitive response. Phytopathology 84:812815.

Weststeijn, E. A. 1984. Evidence for a necrosis-inducing factor in tobacco mosaic virus-infected Nicotiana tabacum cv. Xanthinc grown at $22^{\circ} \mathrm{C}$ but not at $32^{\circ} \mathrm{C}$. Physiol. Plant Pathol. 25:83-91.

Zhu, Y., Qian, W. and Hua, J. 2010. Temperature modulates plant defense responses through NB-LRR proteins. PLoS Pathog. 6:e1000844. 